\title{
Evaluation of Protective Effects of Folinic Acid and Gonadotropin-Releasing Hormone Agonist and Antagonist Against Methotrexate Toxicity in Rats
}

\author{
Folinik Asit, GnRH Agonist veya Antagonist Tedavilerinin Sıçanlarda \\ Metotreksat Toksisitesi Üzerine Koruyucu Etkilerinin Değerlendirilmesi
}

\author{
Tolga Atakul11, (D) Gökalp Öner², (1) Özgür Deniz Turan¹, (D) Serkan Yaşar Çelik³, (D) Mustafa Yılmaz, \\ (D) Hasan Yüksel ${ }^{1}$, (D) Buket Demirci ${ }^{5}$ \\ ${ }^{1}$ Aydın Adnan Menderes University Faculty of Medicine, Department of Obstetrics and Gynecology, Aydın, Turkey \\ ${ }^{2}$ Memorial Kayseri Hospital, Clinic of Obstetrics and Gynecology, Kayseri, Turkey \\ ${ }^{3}$ Muğla Sıtkı Koçman University Faculty of Medicine, Department of Pathology, Muğla, Turkey \\ ${ }^{4}$ Aydın Adnan Menderes University Faculty of Medicine, Department of Biochemistry, Aydın, Turkey \\ ${ }^{5}$ Aydın Adnan Menderes University Faculty of Medicine, Department of Pharmacohology, Aydın, Turkey
}

\begin{abstract}
Objective: A single dose of the folic acid antagonist methotrexate (MTX) is commonly used in ectopic pregnancy. However, the safety of MTX therapy on the ovarian reserve is still controversial. This study aimed to evaluate the use of folinic acid, a gonadotropin-releasing hormone $(\mathrm{GnRH})$ antagonist, and a GnRH agonist on single-dose MTX-induced rat ovarian toxicity.

Methods: A total of 40 Wistar albino rats were randomly divided into five equal groups. Then, all rats were administered MTX intramuscularly. While only physiological saline solution was administered to the control group, only MTX was administered to the MTX group. After $24 \mathrm{~h}$ of MTX administration, the MTX + leucovorin group received leucovorin. The MTX + GnRHa group received triptorelin acetate and MTX simultaneously. The MTX + GnRHant group received cetrorelix acetate with MTX.

Results: The anti-mullerian hormone (AMH) level was similar in the control, MTX, MTX + GnRHa, MTX + GnRHant, and MTX + folinic acid groups. The number of primordial follicles was lower in the MTX group than in the control group $(p=0.004)$, whereas this number in the other groups was similar to that in the control group. AMH levels in the MTX + folinic acid $(p=0.001)$ and MTX $+G n R H a(p=0.002)$ groups were higher than those in the MTX group. The number of primordial, primary, secondary and tertiary follicles was significantly higher in the MTX + folinic acid, MTX + GnRHa, and MTX + GnRHant groups than that in the MTX group.

Conclusions: To the best of our knowledge, this is the first experimental study that can be benefited to minimize the damaging impacts of singledose MTX administration on ovarian reserve and AMH levels. Although the negative impact of single-dose MTX on ovarian reserve is known, our results show that this effect can be minimized by the concurrent administration of GnRHa, GnRHant, or folinic acid. The findings of the present study need to be confirmed with more extensive laboratory studies as well as with randomized controlled clinical studies
\end{abstract}

Keywords: Methotrexate, ovarian reserve, anti-mullerian hormone, gonadotropin-releasing hormone, folinic acid

\section{öz}

Amaç: Ektopik gebeliğin tedavisinde sıklıkla tek bir doz folik asit antagonisti olan metotreksat (MTX) kullanılır. Bununla birlikte, over rezervi üzerinde MTX tedavisinin güvenliği tartışmalıdır. Bu çalışmanın amacı, tek doz MTX kaynaklı sıçan over toksisitesi üzerinde folinik asit, gonadotropin salgılatıcı hormon $(\mathrm{GnRH})$ agonisti ve $\mathrm{GnRH}$ antagonisti etkilerini değerlendirmektir.

Gereç ve Yöntem: Toplam 40 Wistar albino sıçan, rastgele beş eşit gruba ayrıldı. Kontrol grubu dışındaki tüm hayvanlara kas içine MTX enjeksiyonu uygulandı. Kontrol grubuna sadece fizyolojik salin çözeltisi verilirken, MTX grubuna MTX dışında bir tedavi uygulanmadı. MTX +

Address for Correspondence: Tolga Atakul,

Adnan Menderes University Faculty of Medicine, Department of Obstetrics and Gynecology, Aydın, Turkey

Phone: +90 5364759699 E-mail: tolgaatakul@gmail.com ORCID ID: orcid.org/0000-0002-0219-000X

Cite as: Atakul T, Öner G, Turan ÖD, Çelik SY, YIlmaz M, Yüksel H, Demirci B. Evaluation of Protective Effects of Folinic Acid and Gonadotropin-

Releasing Hormone Agonist and Antagonist against Methotrexate Toxicity in Rats. Med J Bakirkoy 2021;17:167-172

Received: 15.05.2020

Accepted: 05.08 .2021 
lökovorin grubuna MTX uygulamasının ardından, 24 saat sonra lökovorin tedavisi uygulandı. MTX + GnRHa grubuna MTX ile eşzamanlı olarak triptorelin asetat ve MTX tedavisi uygulandı. MTX + GnRHant grubuna MTX ile setrorelix asetat tedavisi verildi.

Bulgular: Anti-müllerian hormon (AMH) düzeyi açısından kontrol grubu ile MTX, MTX + GnRHa, MTX + GnRHant ve MTX + folinik asit grupları benzer bulundu. Primordiyal folikül sayısı açısından ise sadece MTX grubunun folikül sayısının kontrol grubuna göre daha düşük olduğu ( $p=0,004)$, diğer grupların ise kontrol grubu ile benzer olduğu bulundu. MTX + folinik asit $(p=0,001)$ ve MTX + GnRHa'nın $(p=0,002) A M H$ düzeyinin sadece MTX ile tedavi edilen gruba göre daha yüksek olduğu bulundu. Primordiyal, primer, sekonder ve tersiyer folikül sayıları MTX'in yanına folinik asit veya $\mathrm{GnRHa}$ veya GnRHant ilave edilen gruplarda, sadece MTX ile tedavi edilen gruba göre anlamlı ölçüde daha yüksekti.

Sonuç: Bildiğimiz kadarıyla, bu çalışma, tek doz MTX uygulamasının over rezervi ve AMH seviyeleri üzerindeki zararlı etkilerini azaltmak için kullanılabilecek ilk deneysel araştırmadır. Tek doz MTX uygulamasının yumurtalık rezervi üzerindeki olumsuz etkisi bilinmesine rağmen, bu çalışmanın sonuçları bu etkinin eşzamanlı GnRHa, GnRHant veya folinik asit uygulamasıyla azaltılabileceğini göstermektedir. Bu sonuçları doğrulamak için, daha kapsamlı laboratuvar çalışmalarına ve randomize kontrollü klinik araştırmalara ihtiyaç vardır.

Anahtar Kelimeler: Metotreksat, yumurtalık rezervi, anti-müllerian hormon, gonadotropin salgılayan hormon, folinik asit

\section{INTRODUCTION}

Along with the early diagnosis, various chemotherapy options have been developed to treat ectopic pregnancies without surgical intervention. The most widely used agent in ectopic pregnancies is methotrexate (MTX) (1). With increasing experience in medical treatment, single-dose regimens of MTX have emerged to simplify treatment, improve compliance, and reduce side effects and costs. $(2,3)$.

Serum anti-mullerian hormone (AMH) correlates best with the number of overleaf follicles. $\mathrm{AMH}$, a member of the TGF- $\beta$ family, is secreted during the development of the primary follicle and can be measured at any time. Its level does not alter much during the menstrual cycle and is almost similar to FSH level. AMH also plays a significant role in maintaining the ovarian reserve by inhibiting the development of primordial follicles (4). In recent years, it has been used clinically for predicting fertility and is frequently used as an adjunct to assisted-reproduction methods $(5,6)$.

Several studies assessing the safety of single-dose MTX have reported controversial results $(7,8)$. Notably, single-dose MTX has a harmful effect on ovaries (9-11). In a study using cisplatin, another drug widely used in cancer treatment, gonadotropin-releasing hormone $(\mathrm{GnRH})$ agonists and antagonists were used to protect against cisplatin-induced ovarian toxicity (12). GnRH is a short-acting decapeptide secreted by the hypothalamus that can cause the pituitary gland to secrete luteinizing hormone and FSH (13). GnRHa is formed by a modification of amino acids 6 and 10 of $\mathrm{GnRH}$, and it has higher biological activity than natural GnRH. It has been reported that the suppression of the female gonadal axis by $\mathrm{GnRHa}$ can minimize the impairment to primordial follicles induced by chemotherapeutic drugs (14). In a prospective experimental study conducted on animals, GnRHa preserved the ovarian reserve by reducing the number of primordial follicles lost during chemotherapy (15). Studies have also reported that $\mathrm{GnRH}$ agonists cause a hypogonadotropic condition, which lowers the amount of primitive follicles entering the differentiation stage, which are more vulnerable to chemotherapy (16). As per a hypothesis, the predicted rise in FSH concentration can be inhibited by $\mathrm{GnRHa}$, and thus saving follicles from accelerated atresia (17). However, the use of $\mathrm{GnRHa}$ is limited owing to the initial aggravation impact of its therapy, which occurs in the first week (17). The protective impact of GnRHant on the ovarian function is manifested through a stronger and faster inhibition of the female gonadal axis $(14,18)$.

The current study aimed to evaluate the histopathological and biochemical effects of a single dose of folinic acid, $\mathrm{GnRH}$ agonist, or $\mathrm{GnRH}$ antagonist in reducing the harmful effects of MTX on rat ovaries.

\section{METHODS}

This experimental study was approved by the Aydın Adnan Menderes University Animal Ethics Committee and followed the principles of good clinical practice and other international guidelines during the entire study period (approval number: HADYEK 64583101/2015/135).

\section{Animals}

In total, 40 female rats (220-270 g) were housed in a room controlled at $24 \pm 2{ }^{\circ} \mathrm{C}$ under a 12 -h dark-light cycle and sufficient ventilation. Food and water were freely available to the animals. All rats had regular menstrual cycles and similar features.

\section{Drugs}

The 40 rats were randomly grouped into five groups $(n=8$ each). The control group was only administered $0.1 \mathrm{~mL}$ saline intramuscularly. In previous studies assessing single-dose MTX, a dose of $50 \mathrm{mg} / \mathrm{m}^{2}$ was preferred; accordingly, we used $50 \mathrm{mg} / \mathrm{m}^{2}$ of MTX in our study (Methotrexate ${ }^{\circledR}$, Koçak Farma, İstanbul, Turkey) (19-21). The MTX group received no additional therapy; however, the MTX + leucovorin group received $0.1 \mathrm{mg} / \mathrm{kg}$ folinic acid (leucovorin) intramuscularly 
$24 \mathrm{~h}$ after MTX administration. The MTX + GnRHa group was administered the $\mathrm{GnRH}$ agonist triptorelin acetate (Decapepty|ß Depot 3.75 mg, Ferring Ilac San. ve Tic. Ltd. Sti, İstanbul, Turkey) subcutaneously at a dose of $1 \mathrm{mg} /$ kg simultaneously with MTX. The MTX + GnRHant group was subcutaneously administered the $\mathrm{GnRH}$ antagonist cetrorelix (Cetrotide $₫ 0.25$ mg, Merck Serono, İstanbul, Turkey) at a dose of $1 \mathrm{mg} / \mathrm{kg}$ concurrent with MTX (9).

To eliminate any direct toxic and sclerosing effects on the ovaries, drugs were not administered intraperitoneally. As a result, treatment effect was assessed using the parenteral route. Following drug administration, a regular cycle schedule for MTX half-life and anti-metabolic effect was devised. Intracardiac blood samples were collected after a 1-month follow-up, and cervical dislocation and oophorectomy were conducted for rats.

\section{AMH Measurement}

The serum AMH level was determined using enzyme-linked immunosorbent assay (ELISA) kits (rat ELISA kit, 201-111246, Baoshan District, Shanghai, Chinese). These kits had a sensitivity of $0.101 \mathrm{ng} / \mathrm{mL}$ with a coefficient variation of $<5 \%$. The processes were conducted in accordance with the manufacturer's guideline.

\section{Histopathology}

Rat ovaries were extracted bilaterally and placed in a buffered $10 \%$ formaldehyde solution overnight and then fixed in paraffin blocks. Subsequently, sections of $5 \mu \mathrm{m}$ thickness were cut and were then deparaffinized and rehydrated before staining with hematoxylin and eosin. Two expert histopathologists categorized oocyte-containing follicles according to developmental phases, and antral follicles in 12 regions of each slice were counted. Follicles were counted and classified in line with the criteria developed by Oktay et al. (22).

Follicles were classified as follows: primordial, primary, secondary, and tertiary (mature) follicles. A primordial follicle is characterized by the presence of a flattened granulosa layer surrounding some or all of the oocyte. A primary follicle is characterized by a single layer of cuboidal granulosa cells covering the oocyte periphery. The secondary follicle has a layer of multiple cuboidal granulosa with a few or nonselectable antral gaps. The oocyte is contiguous with a single large antral area in the tertiary follicle.

\section{Statistical Analysis}

All statistical analyses were performed using SPSS v22.0. Normality check was conducted using the Shapiro-Wilk test. Continuous variables were expressed as means \pm standard deviations, whereas categorical variables were expressed as frequencies and percentages. The ANOVA test was performed to compare the means of groups. Fischer and Games-Howell tests were used in pairwise comparisons. Results with two-tailed $p<0.05$ were considered significant.

\section{RESULTS}

\section{Assessment of Plasma AMH Levels}

AMH levels did not differ among the groups. The AMH level in MTX + leucovorin group $(p=0.001)$ and MTX + triptorelin group ( $p=0.002$ ) was higher than that in the MTX group. However, this level in the MTX + cetrorelix group was lower than that in the MTX + leucovorin $(p=0.018)$ and MTX + triptorelin $(p=0.026)$ groups. In terms of $A M H$ levels, no statistically significant difference was found in the comparisons of other groups (Table 1, Figure 1).

\section{Evaluation of Ovarian Follicle Count}

The number of primordial $(p=0.004)$, primary $(p<0.001)$, secondary $(p<0.001)$, and tertiary follicle $(p<0.001)$ in the MTX group was lower than that in the control group. The number of primary $(p=0.033)$ and tertiary follicles $(p=0.025)$ in the MTX + leucovorin group was lower than that in the control group. The number of primary $(p=0.009)$, secondary $(p=0.005)$, and tertiary $(p<0.001)$ follicles in the MTX + cetrorelix group was lower than that in the control group. Primary $(p=0.004)$, secondary $(p<0.001)$, and tertiary $(p<0.001)$ follicle counts in the MTX + triptorelin group were lower than those in the control group. Primordial $(p=0.011)$, primary $(p<0.001)$, secondary $(p<0.001)$, and tertiary $(p<0.001)$ follicle counts were lower in the MTX group than in the MTX + leucovorin group. Primordial $(p=0.001)$, primary $(p=0.002)$, secondary $(p=0.001)$, and tertiary $(p=0.001)$ follicle counts in the MTX group were lower than those in the MTX + cetrorelix group. In the MTX + triptorelin group, the number of primordial $(p=0.032)$, primary $(p=0.009)$, secondary $(p=0.009)$, and tertiary $(p=0.002)$ follicles was lower than that in the MTX group. The tertiary follicle count was higher in the MTX + leucovorin group than in the MTX + cetrorelix group $(p=0.019)$. Secondary $(p=0.007)$ and tertiary $(p=0.011)$ follicle counts were higher in the MTX + leucovorin group than in the MTX + triptorelin group (Table 1, Figure 1).

\section{DISCUSSION}

MTX reverses and blocks the dihydrofolate reductase enzyme, which prevents the conversion of folic acid to tetrahydrofolic acid. Inhibiting the formation of tetrafolate preventing the synthesis of purine bases (adenine and 


\begin{tabular}{|c|c|c|c|c|c|c|c|}
\hline \multirow[t]{2}{*}{ Groups } & & & \multirow{2}{*}{$\begin{array}{l}\text { Anti-mullerian } \\
\text { hormone }\end{array}$} & \multirow{2}{*}{$\begin{array}{l}\begin{array}{l}\text { Primordial } \\
\text { follicle }\end{array} \\
\text { Mean (SD) }\end{array}$} & \multirow{2}{*}{$\begin{array}{l}\text { Primary } \\
\text { follicle } \\
\text { Mean (SD) }\end{array}$} & \multirow{2}{*}{$\begin{array}{l}\text { Secondary } \\
\text { follicle } \\
\text { Mean (SD) }\end{array}$} & \multirow{2}{*}{$\begin{array}{l}\begin{array}{l}\text { Tertiary } \\
\text { follicle }\end{array} \\
\text { Mean (SD) }\end{array}$} \\
\hline & & & & & & & \\
\hline Control & $(n=8)$ & $=1$ & $4.39(1.34)$ & $65.63(10.13)$ & $57.63(8.50)$ & $49.38(7.07)$ & $17.63(2.50)$ \\
\hline MTX & $(n=8)$ & $=\mathrm{II}$ & $3.53(1.18)$ & $45.50(3.51)$ & $34.50(3.55)$ & $33.63(4.03)$ & 8.75 (1.49) \\
\hline MTX-leucovorin & $(n=8)$ & $=\mathrm{III}$ & $5.45(1.38)$ & $55.38(5.78)$ & $45.75(4.17)$ & $46.88(4.19)$ & $15.13(2.53)$ \\
\hline MTX-cetrorelix & $(n=8)$ & $=\mathrm{IV}$ & $4.10(0.67)$ & $54.00(3.16)$ & $42.88(3.14)$ & $42.38(4.27)$ & $12.50(2.51)$ \\
\hline MTX-triptorelin & $(n=8)$ & $=\mathrm{V}$ & $5.36(0.54)$ & $54.13(6.06)$ & $40.75(2.25)$ & $40.13(2.70)$ & $12.25(1.28)$ \\
\hline$p$ & & & 0.004 & $<0.001$ & $<0.001$ & $<0.001$ & $<0.001$ \\
\hline \multirow{10}{*}{ Pairwise comparison } & III & & $>0.05$ & 0.004 & $<0.001$ & $<0.001$ & $<0.001$ \\
\hline & I-III & & $>0.05$ & $>0.05$ & 0.033 & $>0.05$ & 0.025 \\
\hline & I-IV & & $>0.05$ & $>0.05$ & 0.009 & 0.005 & $<0.001$ \\
\hline & $\mathrm{I}-\mathrm{V}$ & & $>0.05$ & $>0.05$ & 0.004 & $<0.001$ & $<0.001$ \\
\hline & II-III & & 0.001 & 0.011 & $<0.001$ & $<0.001$ & $<0.001$ \\
\hline & II-IV & & $>0.05$ & 0.001 & 0.002 & 0.001 & 0.001 \\
\hline & II-V & & 0.002 & 0.032 & 0.009 & 0.009 & 0.002 \\
\hline & III-IV & & 0.018 & $>0.05$ & $>0.05$ & $>0.05$ & 0.019 \\
\hline & III-V & & $>0.05$ & $>0.05$ & $>0.05$ & 0.007 & 0.011 \\
\hline & IV-V & & 0.026 & $>0.05$ & $>0.05$ & $>0.05$ & $>0.05$ \\
\hline
\end{tabular}

MTX: Methotrexate, SD: Standard deviation, Statistically significant are indicated in bold

guanine) that are necessary for DNA, RNA, and ATP synthesis and protein synthesis disruption. This consequently limits the conversion to deoxyuridylatedimidilate, which is necessary for DNA synthesis and cell regeneration (23). Single-dose MTX is the gold standard treatment for unruptured ectopic pregnancy. The success rate of single-dose MTX in ectopic pregnancy varies between $64 \%$ and $94 \%$ (24). Although this treatment option significantly reduces the need for surgical intervention, especially in patients with early onset and without obvious clinical symptoms, it has recently been reported to have adverse effects on the ovaries and to reduce ovarian reserve $(10,11)$. In this study, we aimed to assess the protective effects of folinic acid, GnRHa, and GnRHant against the harmful effects of MTX on the ovarian reserve.

In this study, AMH levels were measured and follicles were enumerated to accurately identify the ovarian reserve and to histopathologically distribute and count the follicular series. There was no significant difference between the control group and other groups in terms of $\mathrm{AMH}$ levels. The number of primordial follicles of the MTX group was lower than that of the control group, whereas this number in the other groups was similar to that in the control group.

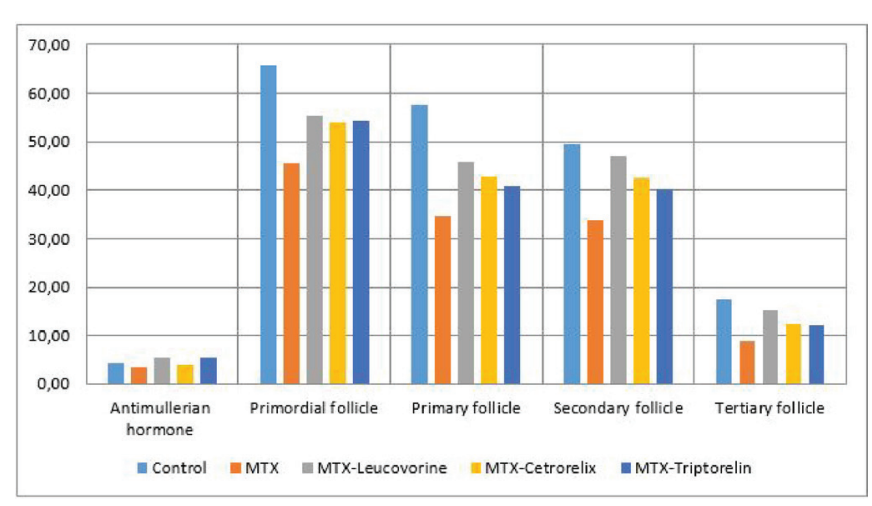

Figure 1. In the control group, there is a significant increase in the number of all follicles compared with in the other groups. The MTX group has a significantly decreased number of all follicular series and $\mathrm{AMH}$ levels compared with the other groups. All follicle groups and $\mathrm{AMH}$ levels were normal in the MTX + leucovorin group compared to other groups

MTX: Methotrexate

In addition, we found that the AMH level was higher in the folinic acid and GnRHa groups treated with MTX than that in the MTX group. In addition, the number of primordial, primary, secondary, and tertiary follicles were significantly higher in the groups treated with MTX and folinic acid, GnRHa, or GnRHant than the group treated with only MTX. 
Recent studies on the use of MTX for ectopic pregnancy have shown that MTX treatment does not change the oocyte count in women undergoing ovarian stimulation for assisted-reproductive technology. However, it is interesting that very few of these studies evaluated antral follicle count $(7,25)$. In a study evaluating 7 ectopic pregnancy cases of 329 cases who received assisted-reproductive technology treatment, MTX used for ectopic pregnancy did not affect the number of follicles and fertility (26). In the study by Uyar et al. (9) single-dose MTX treatment in ectopic pregnancy cases did not have a negative effect on the ovarian reserve, as assessed by basal FSH, E2, basal antral follicle number, and ovarian volume. Shirazi et al. (27) reported no adverse effect of MTX on the ovarian reserve as assessed by $\mathrm{AMH}$ level. Oriol et al. (28) reported that single dose-MTX did not have a negative effect on the ovarian reserve, since AMH levels did not differ in patients with ectopic pregnancy. A meta-analysis evaluating ectopic pregnancy cases reported no significant difference in oocyte counts before and after MTX treatment (29). In another study conducted on rats, MTX significantly reduced the AMH level and the total number of follicles (30). In our study, AMH level, one of the ovarian reserve markers, was found to be similar in the MTX group and the control group; however, the follicle counts in the MTX group were lower than those in the control group. It should be noted that single-dose MTX, which is used in ectopic pregnancy and is a part of routine practice, is not as safe as previously thought.

Yuan et al. (31) evaluated the effects of cyclophosphamide on the ovaries of rats treated with $\mathrm{GnRHa}$ and found that FSH, estradiol, and follicle numbers were significantly higher in the GnRHa group. Moreover, GnRHa reduced ovarian damage after cyclophosphamide treatment (31). In the study conducted by Peng et al. (32) in rats, GnRHa was effective in preventing ovarian function damage caused by cyclophosphamide, but GnRHant was not effective. In another study conducted by Parlakgumus et al. (33) in rats, neither GnRHa nor GnRHant provided protection against cyclophosphamide-induced damage and GnRHant reduced the number of primordial follicles. In our study, GnRHa and GnRHant had a protective effect on the ovarian reserve affected by MTX in terms of follicle numbers; however, only $\mathrm{GnRHa}$ was protective in terms of $\mathrm{AMH}$. The $\mathrm{AMH}$ level in the GnRHa group was higher than that in the GnRHant group. Therefore, it can be said that $\mathrm{GnRHa}$ is a slightly better than MTX in protecting against the harmful effects on the ovary.
$\mathrm{Li}$ et al. (12) reported that the combined use of $\mathrm{GnRH}$ agonists and antagonists helped reduce cisplatin-induced ovarian toxicity in rats. In our study, the effect of GnRHa in combination with GnRHant was not assessed. This is one of the limitations of the research. As a result of not assessing the combining the effects of GnRHa and GnRHant, the expected protective effect may have been reduced owing to the exacerbation effect.

\section{Study Limitations}

Another important limitation of this study is that the longterm effects of single-dose MTX on ovarian reserve were not evaluated. Despite these limitations, this work is, to our knowledge, the pioneer study of agents that can be used to reduce the detrimental effects MTX on follicle number and $\mathrm{AMH}$ levels.

Based on our analyzes on the negative effects on ovarian reserve following MTX treatment, it can be said that folinic acid, GnRHa, and GnRHant provide protection against altered follicle numbers. Folinic acid and $\mathrm{GnRHa}$ are better as they significant increase the AMH level.

\section{CONCLUSION}

Our results may help guide treatment with single doseMTX. The results found can be confirmed by more extensive laboratory studies and randomized controlled trials.

\section{ETHICS}

Ethics Committee Approval: This experimental study was approved by the Aydın Adnan Menderes University Ethics Committee and followed the principles of good clinical practice and other international guidelines during the entire study period (approval number: HADYEK 64583101/2015/135).

Informed Consent: Not applicable.

\section{Authorship Contributions}

Surgical and Medical Practices: T.A., G.Ö., Ö.D.T., Concept: T.A., S.Y.C.., M.Y., Design: T.A., B.D., Data Collection or Processing: G.Ö., Ö.D.T., S.Y.Ç., Analysis or Interpretation: T.A., M.Y., H.Y., Literature Search: T.A., G.Ö., S.Y.Ç., Writing: T.A., G.Ö., Ö.D.T., S.Y.Ç., M.Y., H.S.Y., B.D.

Conflict of Interest: No conflict of interest was declared by the authors.

Financial Disclosure: The authors declared that this study received no financial support.

\section{REFERENCES}

1. van Mello NM, Mol F, Adriaanse AH, Boss EA, Dijkman AB, Doornbos JP, et al. The METEX study: methotrexate versus 
expectant management in women with ectopic pregnancy: a randomised controlled trial. BMC Womens Health 2008;8:10.

2. Lecuru F, Robin F, Bernard JP, Maizan de Malartic C, Mac-Cordick C, et al. Single-dose methotrexate for unruptured ectopic pregnancy. Int J Gynaecol Obstet 1998;61:253-9.

3. Alsammani MA, Moona NA. Predictors of Success of a Single-Dose Methotrexate in the Treatment of Ectopic Pregnancy. J Obstet Gynaecol India 2016;66:233-8.

4. Visser JA, de Jong FH, Laven JS, Themmen AP. Anti-Müllerian hormone: a new marker for ovarian function. Reproduction 2006;131:1-9.

5. Weenen C, Laven JS, Von Bergh AR, Cranfield M, Groome NP, Visser JA, et al. Anti-Müllerian hormone expression pattern in the human ovary: potential implications for initial and cyclic follicle recruitment. Mol Hum Reprod 2004;10:77-83.

6. Broer SL, Eijkemans MJ, Scheffer GJ, van Rooij IA, de Vet A, Themmen AP, et al. Anti-mullerian hormone predicts menopause: a long-term follow-up study in normoovulatory women. J Clin Endocrinol Metab 2011;96:2532-9.

7. Boots CE, Gustofson RL, Feinberg EC. Does methotrexate administration for ectopic pregnancy after in vitro fertilization impact ovarian reserve or ovarian responsiveness? Fertil Steril 2013;100:1590-3.

8. Sukhotnik I, Nativ O, Roitburt A, Bejar D, Coran AG, Mogilner JG, et al. Methotrexate induces germ cell apoptosis and impairs spermatogenesis in a rat. Pediatr Surg Int 2013;29:179-84.

9. Uyar I, Yucel OU, Gezer C, Gulhan I, Karis B, Hanhan HM, et al. Effect of single-dose methotrexate on ovarian reserve in women with ectopic pregnancy. Fertil Steril 2013;100:1310-3.

10. Benian A, Guralp O, Uzun DD, Okyar A, Sahmay S. The effect of repeated administration of methotrexate (MTX) on rat ovary: measurement of serum antimullerian hormone (AMH) levels. Gynecol Endocrinol 2013;29:226-9.

11. Ulug $P$, Oner $G$. Evaluation of the effects of single or multiple dose methotrexate administration, salpingectomy on ovarian reserve of rat with the measurement of anti-Müllerian hormone (AMH) levels and histological analysis. European Journal of Obstetrics \& Gynecology and Reproductive Biology 2014;181:205-9.

12. Li X, Kang X, Deng $Q$, Cai J, Wang Z. Combination of a GnRH agonist with an antagonist prevents flare-up effects and protects primordial ovarian follicles in the rat ovary from cisplatin-induced toxicity: a controlled experimental animal study. Reprod Biol Endocrinol 2013;11:16.

13. Blumenfeld Z, Eckman A. Preservation of fertility and ovarian function and minimization of chemotherapy-induced gonadotoxicity in young women by $\mathrm{GnRH}$-a. J Natl Cancer Inst Monogr 2005;(34):40-3.

14. Huang $\mathrm{YH}$, Zhao XJ, Zhang $\mathrm{QH}$, Xin XY. The GnRH antagonist reduces chemotherapy-induced ovarian damage in rats by suppressing the apoptosis. Gynecol Oncol 2009;112:409-14.

15. Ataya K, Rao LV, Lawrence E, Kimmel R. Luteinizing hormonereleasing hormone agonist inhibits cyclophosphamide-induced ovarian follicular depletion in rhesus monkeys. Biol Reprod 1995;52:365-72.

16. Lobo RA. Potential options for preservation of fertility in women. N Engl J Med 2005;353:64-73.

17. Blumenfeld Z. How to preserve fertility in young women exposed to chemotherapy? The role of GnRH agonist cotreatment in addition to cryopreservation of embrya, oocytes, or ovaries. Oncologist 2007;12:1044-54.

18. Parborell F, Irusta G, Vitale A, Gonzalez O, Pecci A, Tesone M. Gonadotropin-releasing hormone antagonist antide inhibits apoptosis of preovulatory follicle cells in rat ovary. Biol Reprod 2005;72:659-66.
19. Saleh H, Mowafy H, Abd El Hameid A, Abdelsalam W, Sherif H. Double versus single dose methotrexate regimens in management of undisturbed ectopic pregnancy. Obstet Gynecol Int J 2016;5:00184.

20. Song T, Kim MK, Kim ML, Jung YW, Yun BS, Seong SJ. Single-dose versus two-dose administration of methotrexate for the treatment of ectopic pregnancy: a randomized controlled trial. Hum Reprod 2016;31:332-8.

21. Golmohammadlou S, Hajishafiha M, Yekta D, Hasankhani D. Comparision of single and two dose of methotrexate in treatment of ectopic pregnancy. Stud Med Sci 2012;23:417-21.

22. Oktay K, Schenken RS, Nelson JF. Proliferating cell nuclear antigen marks the initiation of follicular growth in the rat. Biol Reprod 1995;53:295-301.

23. Gol M, Saygili U, Koyuncuoglu M, Uslu T. Influence of high-dose methotrexate therapy on the primordial follicles of the mouse ovary. J Obstet Gynaecol Res 2009;35:429-33.

24. Barnhart KT, Gosman G, Ashby R, Sammel M. The medical management of ectopic pregnancy: a meta-analysis comparing "single dose" and "multidose" regimens. Obstet Gynecol 2003;101:778-84.

25. Wiser A, Gilbert A, Nahum R, Orvieto R, Haas J, Hourvitz A, et al. Effects of treatment of ectopic pregnancy with methotrexate or salpingectomy in the subsequent IVF cycle. Reprod Biomed Online 2013;26:449-53.

26. Desroque D, Capmas P, Legendre G, Bouyer J, Fernandez H. Fertilité après grossesse extra-utérine [Fertility after ectopic pregnancy]. J Gynecol Obstet Biol Reprod (Paris) 2010;39:395-400.

27. Shirazi M, Pooransari P, Hajiha N, Shaker Z, Ghazi M, Davari Tanha $F$, et al. Effect of Single-Dose Methotrexate Treatment on Ovarian Reserve in Women with Ectopic Pregnancy Undergoing Infertility Treatment: A Single-Center Experience. Int J Fertil Steril 2020;14:23-6.

28. Oriol B, Barrio A, Pacheco A, Serna J, Zuzuarregui JL, GarciaVelasco JA. Systemic methotrexate to treat ectopic pregnancy does not affect ovarian reserve. Fertil Steril 2008;90:1579-82.

29. Ohannessian A, Loundou A, Courbière B, Cravello L, Agostini A. Ovarian responsiveness in women receiving fertility treatment after methotrexate for ectopic pregnancy: a systematic review and meta-analysis. Hum Reprod 2014;29:1949-56.

30. Soylu Karapinar O, Pinar N, Özcan O, Özgür T, Dolapçığlu K. Protective effect of alpha-lipoic acid in methotrexate-induced ovarian oxidative injury and decreased ovarian reserve in rats. Gynecol Endocrinol 2017;33:653-9.

31. Yuan GW, Shen K, Yang JX. [Study of the prevention of chemotherapy-induced ovarian damage by gonadotropinreleasing hormone agonist in rat model]. Zhonghua Fu Chan Ke Za Zhi 2005;40:666-9.

32. Peng P, Yang DZ, Zheng CY, Mo YQ, He YM, Zhang QX. [Effects of gonadotropin releasing hormone analogues on chemotherapyinduced ovarian function damage in rats]. Zhonghua Fu Chan Ke Za Zhi 2007:42:546-50.

33. Parlakgumus HA, Kilicdag EB, Bolat FA, Haydardedeoglu B, Parlakgumus $A$. GNRH agonists and antagonists in rescue for cyclophosphamide-induced ovarian damage: friend or foe? Arch Gynecol Obstet 2015;291:1403-10. 